\title{
Evaluation of growth performance and gastro-intestinal parameters on the response of weaned piglets to dietary organic acids
}

\author{
HENRIQUE A.T. GRECCO ${ }^{1}$, ALESSANDRO B. AMORIM ${ }^{2}$, MAYRA A.D. SALEH ${ }^{1}$, MARCOS L.P. TSE ${ }^{1}$, \\ FILIPE G. TELLES ${ }^{1}$, GABRIELA M. MIASSI ${ }^{1}$, GUILHERME M. PIMENTA ${ }^{3}$ and DIRLEI A. BERTO ${ }^{1}$ \\ ${ }^{1}$ Departamento de Produção Animal, Faculdade de Medicina Veterinária e Zootecnia, Universidade Estadual Paulista/ \\ UNESP, Fazenda Experimental Lageado, Rua Dr. José Barbosa de Barros, 1780, 18610-307 Botucatu, SP, Brazil \\ ${ }^{2}$ Instituto de Ciências Agrárias e Tecnológicas, Universidade Federal do Mato Grosso/ \\ UFMT, Avenida dos Estudantes, 5005, 78735-902 Rondonópolis, MG, Brazil \\ ${ }^{3}$ Instituto de Biociências, Centro de Isótopos Estáveis Ambientais, Universidade Estadual Paulista/ \\ UNESP, Rua Prof Dr. Antonio Celso Wagner Zanin, 250, 18618-689 Botucatu, SP, Brazil
}

Manuscript received on February 1, 2016; accepted for publication on July 13, 2016

\begin{abstract}
Two experiments (E) were carried out to evaluate the effects of fumaric acid and an acidifier blend [composed by calcium formate, calcium lactate and medium-chain fatty acids (capric and caprylic)] in piglet diets containing colistin $(40 \mathrm{ppm})$ or halquinol $(120 \mathrm{ppm})$ on performance, diarrhea incidence (E1), organs relative weight, $\mathrm{pH}$ values, intestinal morphometry and microbiota (E2). In E1, 192 and E2, 24 piglets weaned at 21-day-old were randomly assigned to blocks with $2 \times 2$ factorial arrangement of treatments [absence or presence of fumaric acid $x$ absence or presence of acidifier blend], six replicates of eight (E1) and one piglet per pen (E2). For E1, the treatments were control (CD): no acidifier product +40 ppm of colistin, FA: fumaric acid in absence of acidifier blend, AB: acidifier blend in absence of fumaric acid and, $\mathrm{AF}+\mathrm{AB}$ : presence of fumaric acid and acidifier blend. For E2, the pre-starter I diet were used and the same treatments as E1 evaluated. No treatment effects $(\mathrm{P}>0.05)$ were observed on performance, diarrhea incidence (E1), gut $\mathrm{pH}$ values and duodenum morphometry of piglets (E2). However, the addition of $\mathrm{AB}$ increased $(\mathrm{P}<0.05)$ large intestine relative weight and, FA addition decreased $(\mathrm{P}<0.05)$ pancreas relative weight, jejunum villi height and, total coliform and $E$. coli counts in cecum. The inclusion of FA and $\mathrm{AB}$ in diets containing colistin or halquinol did not improve performance, although FA exerted an inhibitory effect on cecum microbiota.
\end{abstract}

Key words: acidifiers, diarrhea, nutrition, pig, weaning.

\section{INTRODUCTION}

Early-weaning is one of the most critical management practices in piglet's life, which constitutes a challenge for them and results in

Correspondence to: Mayra Anton Dib Saleh

E-mail: dib_saleh@yahoo.com.br poor growth performance, reduced immunity, and an imbalanced microbiota. The main factors contributing to these results are low feed intake and onset of diarrhea (Barnett et al. 1989). At weaning, the piglets that were physiologically adapted to digest the sow's milk are abruptly submitted to a diet with high amount of vegetable ingredients, 
usually a cereal like corn as main energy source and high in starch (Vente-Spreeuwenberg et al. 2003), and another vegetable protein source like soybean meal, for which they are not prepared to digest due to its insufficient production of gastric hydrochloric acid that leads to an increased $\mathrm{pH}$ and decreased activity of proteolytic enzymes. Besides that, the lactic acid produced by fermentation of lactose is primarily responsible for acidification of suckling pig stomach and, according to Barrow et al. (1977), this acid acts as HCl-production inhibitor. Also, the presence of large amount of soybean meal in piglets' diet might cause hypersensitivity reactions which result on altered bowel structures (the villi) hindering the digestion of feed and absorption of nutrients (Li et al. 1990). Therefore, the use of enhancing additives can be an alternative to compensate these deficiencies.

Concerning the appearance of resistant bacteria and residues in animal products, the European Union has been prohibited the use of antibiotics as performance-enhancing antimicrobial compounds. Thus, the interest for alternative products, such as organic acids and their salts have increased by the consumer, due to its antimicrobial activity and safety (Blank et al. 2001, Costa et al. 2011). According to Cherrington et al. (1991), these products leave no residues in carcass and do not promote emergence of resistant bacteria, being a natural, safe, and inexpensive alternative to antibiotics in order to improve the health and performance of animals. For pigs, the most commonly used acids are acetic, formic, propionic, lactic, citric and fumaric acid (Partanen 2002), and the efficiency of organic acids in improving piglet's growth performance have been confirmed by other studies (Giesting and Easter 1985, Radecki et al. 1988, Radcliffe et al. 1998).

Therefore, this study aimed to evaluate the effects of dietary supplementation of fumaric acid and an acidifier blend [calcium formate, calcium lactate and medium-chain fatty acids (capric and caprylic)] on growth performance, organs weight,
$\mathrm{pH}$, morphometry and intestinal microbiota of weaned piglets.

\section{MATERIALS AND METHODS}

All experimental procedures were previously approved by the Animal Ethics Commitee of the Veterinary and Animal Science College from São Paulo State University (UNESP), under protocol number 187/2012-CEUA and, in accordance with directive 2010/63/EU.

\section{EXPERIMENT 1}

The experiment was conducted in a nursery facility at a commercial farm in city of Patos de Minas, Minas Gerais State, Brazil. The nursery stall was divided into three rooms, with ceiling height of 2.40 $\mathrm{m}$, and eight pens each, totaling twenty-four pens. Each pen had $4.64 \mathrm{~m}^{2}$ with a partially slatted and not suspended flooring, two nipple-type drinkers and a semi-automatic feeder for seven piglets. A hundred forty and four male piglets (castrated) and fortyeight females, totaling 192 animals, from Agroceres PIC genetics (Pietrain/Landrace x Duroc/Landrace) were weaned at 21-day-old with average initial body weight of $6.80 \pm 0.89 \mathrm{~kg}$. The control temperature within each nursery room was carried out with the management of lateral curtains and heaters.

The experiment duration lasted 41 days and the piglets were fed three types of diets (Table I) according to a nursery feeding system in phases: prestarter diet I (PI) in the first 14 days after weaning (from 21 - to 35-day-old), pre-starter diet II (PII) in the following 14 days (from 36- to 49-day-old) and, starter diet (SI) until the end of the experiment (from 50- to 62-day-old). The formulated diets followed the nutritional requirements proposed by Rostagno et al. (2011), except for calcium. All animals had ad libitum access to feed and water.

The experimental design was a randomized block design with four treatments, six replicates and eight animals per experimental unit, in a 
factorial arrangement [absence or presence of fumaric acid (FA) $x$ absence or presence of acidifier blend (AB)]. The variables considered for blocks formation were the weight and sex of animals.

The treatments were CD: PI, PII and SI diets without acidifier product; FA: PI, PII, and SI diets containing $0.8 \%, 0.4 \%$ and $0.2 \%$ of fumaric acid, respectively; AB: PI, PII, and SI diets containing $0.3 \%, 0.3 \%$ and $0.2 \%$ of acidifier blend, respectively; $\mathrm{AB}+\mathrm{FA}$ : PI, PII, and SI diets containing $0.8 \%, 0.4 \%$ and $0.2 \%$ of fumaric acid and $0.3 \%, 0.3 \%$ and $0.2 \%$ of acidifier blend respectively. For all treatments, $40 \mathrm{ppm}$ of colistin were added to PI and PII diets and, $120 \mathrm{ppm}$ of halquinol were added to SI diets. The acidifier product used was a mixture of calcium formate, calcium lactate salts and medium-chain fatty acids (capric and caprylic). The inclusions of acidifier, the colistin sulphate and the halquinol in feed were possible by the substitution of equivalent amount of inert material (kaolin).

At beginning of experiment and at each diet switch, the piglet weight was measured individually. At periods 0 to 14,0 to 28 and 0 to 42 days after weaning, the daily feed intake, daily weight gain and feed:gain ratio were evaluated. During the first 14 days of experiment, the diarrhea incidence was evaluated twice a day by the same observer. Diarrhea status was considered when visually faeces had fluid consistency. The values of diarrhea incidence were calculated as mean percentage of animals with diarrhea in the pen (p), and the data were subjected to angular transformation: $p^{\prime}=\arcsin e^{*}[\sqrt{ }(p / 100)]$ for further analysis of variance. The animals were housed in pens that have not undergone to previous disinfection. The diet $\mathrm{pH}$ was evaluated according to the following methodology (AOAC 1990): $5 \mathrm{~g}$ of feed sample was weighed into a $100 \mathrm{~mL}$ becker, following 25 $\mathrm{mL}$ of de-ionized water addition. After mixing the solution and waiting for $30 \mathrm{~min}$, the $\mathrm{pH}$ of solution was registered by a portable Tecnopon $\mathrm{pH}$ meter (model mPa-210P, Piracicaba, Brazil).

All data were analyzed using the GLM procedure of SAS 9.0 (SAS 2002). Tukey's multiple range tests were applied to test significant differences between treatments. For all of statistical analysis for this work, the pen served as an experimental unit. Variability in the data was expressed as coefficient of variation $(\mathrm{CV})$ and a probability level of $(\mathrm{P}<0.05)$ was considered as statistically significant.

\section{EXPERIMENT 2}

The second experiment was conducted in experimental swine production facilities from Faculty of Veterinary Medicine and Animal Science at São Paulo State University (UNESP), Botucatu Campus, Brazil with twelve castrated males and twelve females piglets from commercial genetics (Landrace x Large White) weaned at 21-day-old with an average body weight of $6.46 \pm 0.24 \mathrm{~kg}$. The nursery facility had metal suspended pens of 1.75 $\mathrm{m}^{2}$ and, a partially slatted flooring with a compact concrete floor under the heater, being equipped with one feeder, one nipple-type drinker and one heater.

The experimental design was a randomized block design with four treatments, six replicates and one animal per experimental unit. The experiment duration lasted 14 days, during which the animals were fed pre-starter I diets (PI) (Table I). All treatments were the same as defined in Experiment I.

At $14^{\text {th }}$ experimental day, all piglets were slaughtered after electrical stunning. A longitudinal incision was made along abdominal cavity for removal of digestive organs. The gastrointestinal tract (with contents) was weighed by full and after removing the stomach, small intestine, cecum and large intestine content, they were weighed again, one by one, to determine its absolute weight. The liver, pancreas, spleen and kidneys were also weighed in order to determine their absolute 
TABLE I

Composition of experimental diets provided to piglets from 21- to 62-day-old.

\begin{tabular}{|c|c|c|c|}
\hline \multicolumn{4}{|c|}{ Diets } \\
\hline Ingredients & $\mathbf{P I}^{1}$ & PII $^{2}$ & $\mathrm{SI}^{3}$ \\
\hline Corn & 31.70 & 45.70 & 62.07 \\
\hline Soybean meal & 25.00 & 27.00 & 31.00 \\
\hline Cracker/biscuit residue & 10.00 & 7.00 & - \\
\hline Spray-dried blood meal & 1.20 & 0.25 & - \\
\hline Whey & 12.00 & 6.00 & - \\
\hline Energetic concentrate $^{4}$ & 3.00 & 2.00 & 3.00 \\
\hline Sugarcane yeast & 1.00 & 0.50 & - \\
\hline Pregelatinized corn & 3.37 & 1.94 & 0.74 \\
\hline Extruded soybean and viscera & 8.00 & 5.00 & - \\
\hline Mineral and vitamin premix ${ }^{5}$ & 0.40 & 0.40 & 0.50 \\
\hline Dicalcium phosphate (18\%) & 1.08 & 1.38 & 0.97 \\
\hline Ground limestone (37\%) & 0.25 & 0.13 & 0.26 \\
\hline Salt & 0.21 & 0.40 & 0.50 \\
\hline Sweetener ${ }^{6}$ & 0.30 & 0.30 & 0.30 \\
\hline Inert (kaolin $)^{7}$ & 1.10 & 0.70 & 0.40 \\
\hline Fumaric acid & $*$ & $*$ & $*$ \\
\hline Acidifier blend $^{8}$ & $*$ & $*$ & $*$ \\
\hline Colistin (4\%) & 0.10 & 0.10 & - \\
\hline $\mathrm{ZnO}(73 \%)$ & 0.29 & 0.30 & - \\
\hline $\mathrm{CuSO}_{4}(25 \%)$ & 0.07 & 0.07 & - \\
\hline Halquinol (60\%) & - & - & 0.02 \\
\hline L-Lys HCl $(80 \%)$ & 0.49 & 0.45 & 0.16 \\
\hline DL-Met (99\%) & 0.22 & 0.19 & 0.03 \\
\hline L-Thr (98\%) & 0.17 & 0.15 & 0.03 \\
\hline L-Trp $(99 \%)$ & 0.03 & 0.02 & - \\
\hline Total $(\mathrm{kg})$ & 100.00 & 100.00 & 100.00 \\
\hline \multicolumn{4}{|l|}{ Calculated values } \\
\hline $\begin{array}{l}\text { Metabolizable energy ( } \mathrm{kcal} \\
\left.\mathrm{kg}^{-1}\right)^{9}\end{array}$ & 3,411 & 3,352 & 3,284 \\
\hline Crude protein $(\%)$ & 21.86 & 20.24 & 20.18 \\
\hline $\mathrm{Ca}(\%)$ & 0.69 & 0.63 & 0.78 \\
\hline Digestible P (\%) & 0.46 & 0.45 & 0.40 \\
\hline Digestible Lys (\%) & 1.46 & 1.31 & 1.09 \\
\hline Digestible Met (\%) & 0.52 & 0.48 & 0.32 \\
\hline Digestible Thr (\%) & 1.12 & 0.81 & 0.68 \\
\hline Digestible Trp (\%) & 0.24 & 0.22 & 0.19 \\
\hline Lactose-equivalent (\%) & 10.00 & 5.00 & - \\
\hline
\end{tabular}

${ }^{1} \mathrm{PI}$ : pre-starter I diet [treatment FA with $0.8 \%$ fumaric acid (FA); treatment $\mathrm{AB}$ with $0.3 \%$ acidifier blend $(\mathrm{AB})$ and treatment $\mathrm{FA}+\mathrm{AB}$ with $0.8 \%$ fumaric acid plus $0.3 \%$ acidifier blend]. ${ }^{2} \mathrm{PII}$ : pre-starter II diet [treatment FA with $0.4 \%$ fumaric acid (FA); treatment $\mathrm{AB}$ with $0.3 \%$ acidifier blend $(\mathrm{AB})$ and treatment $\mathrm{FA}+\mathrm{AB}$ with $0.4 \%$ fumaric acid plus $0.3 \%$ acidifier blend]. ${ }^{3} \mathrm{SI}$ : starter I diet [treatment FA with $0.2 \%$ fumaric acid (FA); treatment $\mathrm{AB}$ with $0.2 \%$ acidifier blend (AB) and treatment $\mathrm{FA}+\mathrm{AB}$ with $0.2 \%$ fumaric acid plus $0.2 \%$ acidifier blend]. ${ }^{4}$ Energipig ${ }^{\circledR}$ : ground corn, extruded soybean, biscuit meal, corn germen meal, vanilla flavor, soy lecithin, enzimatic additive, propionic acid, monosodium glutamate, etoxiquin and, butylated hydroxy toluene. ${ }^{5}$ Agroceres ${ }^{\circledR}$ (supplied per $\mathrm{kg}$ of diet): Vit. A - 4,000 I.U.; Vit. $\mathrm{D}_{3}-220$ I.U.; Vit. E - $22 \mathrm{mg}$; Vit. K - 0.5 mg; Vit, $\mathrm{B}_{2}-3.75 \mathrm{mg}$; Vit. $\mathrm{B}_{12}-20 \mu \mathrm{g}$; Calcium pantothenate - $12 \mathrm{mg}$; Niacin - $20 \mathrm{mg}$; Choline - $60 \mathrm{mg}$; I - $140 \mu$ g; Se - $300 \mu$ g; Mn - 10 mg; Zn - 100 mg; Cu - 10 $\mathrm{mg} ; \mathrm{Fe}-99 \mathrm{mg}$. Nutritional values according to Rostagno et al. (2011). ${ }^{6}$ Flavofix ${ }^{\circledR}$ (supplied per kg of feed): neohesperidin dihydrochalcone $-1,200 \mathrm{mg} / \mathrm{kg}$; sodium saccharin $-58.20 \mathrm{~g} /$ $\mathrm{kg}$; vanilla flavor $-25 \mathrm{~g} / \mathrm{kg},{ }^{7} \mathrm{The}$ inclusions of acidifier, the colistin sulphate and the halquinol in feed were possible by the substitution of equivalent amount of inert material (kaolin). ${ }^{8} \mathrm{AgAcid}^{\mathbb{Q}}$ : calcium formate, calcium lactate, medium-chain fatty acids (capric and caprylic acids). ${ }^{9}$ Calculated values without considering the energetic contribution from FA and $\mathrm{AB}$.

weights. After this procedure, the relative weight of each organ was calculated based on the empty carcass weight (weight with no digesta content). Also $\mathrm{pH}$ readings of stomach, jejunum, ileum and colon contents were measured immediately after slaughter by a portable Tecnopon $\mathrm{pH}$ meter (model $\mathrm{mPa}-210 \mathrm{P}$, Piracicaba, Brazil).

The cecum of each animal was removed with its content and stored in styrofoam boxes with ice for further laboratory analysis. The total coliform and Escherichia coli counts were measured from $10 \mathrm{~g}$ of cecal content, and then added to $90-\mathrm{mL}$ of $0.85 \%$ saline and homogenized for $2 \mathrm{~min}$, obtaining a 10:1 dilution. After, a serial decimal dilutions were prepared, transferred to $1-\mathrm{mL}$ of ECTM Petri dishes and incubated at $35^{\circ} \mathrm{C}$ for $24-$ hour (AOAC 2000). The Lactobacillus spp. count was performed from decimal serial dilutions as described for Escherichia coli count, transferring 0.1-mL into Petri dishes containing Man-RogosaSharpe (surface sowing), incubated at $30^{\circ} \mathrm{C}$ for 5 days in a drying air oven with $5 \% \mathrm{CO}_{2}$ atmosphere 
(Downes and Ito 2001). Microflora enumerations were expressed as $\log ^{10}$ colony-forming unit (cfu) per gram.

For gut morphometry analysis, samples were collected from $1.5 \mathrm{~cm}$ of duodenum and jejunum initial and middle portions which were immersed in $10 \%$ formalin solution for 48 -hour. Then, samples were immersed in $70 \%$ etanol solution, dehydrated in ethyl alcohol (increasing concentrations). The tissue fragments were cut about $1.0 \mathrm{~cm}$ in each segment, diaphanized in benzene and embedded in paraffin. Four semi-serial sections of segments (jejunum and duodenum) with $5 \mu \mathrm{m}$ thickness were performed for each animal. After processing, the sections were placed on slides, stained by hematoxylin and eosin technique and examined under a light microscope for villi height and width, crypt depth measurements using Leica QWin image processing and analysis workstation software. Thirty readings were performed for each animal and each segment. The final result was the average of 30 measurements.

The scanning electron microscopy technique was used to evaluate the villi density. Duodenum and jejunum samples collected after slaughter were fixed in 3\% glutaraldehyde, washed in $0.1 \mathrm{M}$ sodium cacodylate, buffered in $\mathrm{pH} 7.2$, post-fixed in $1 \%$ osmium tetroxide. Then, samples were washed in the same buffer and dehydrated in an increasing ethanol concentration. The tissue samples were soacked into isoamyl acetate solution for 3-hour. Drying was performed obtaining the critical point of liquid $\mathrm{CO}_{2}$ in a dry air oven SEM model 850. A Denton Desk II model vacuum device was used for sputter coated (gold-palladium). The samples were mounted over supports of $1.0 \mathrm{~cm}$ in diameter and thickness, using metal tape, observed and registered by a scanning electron microscope JEOL JSM 5410, operated at accelerating voltage of 15 $\mathrm{kV}$. The eletron micrographs from four samples were taken counting the villi. Then, to assess the approximate magnitude of the absorptive area per
$1 \mathrm{~mm}^{2}$ of the intestinal mucosa $\left(\mathrm{mm}^{2} / \mathrm{mm}^{2}\right)$, the surface of villi was calculated and multiplied by the number of villi, using the following equation: $\pi r^{2}+2 \pi r h$, where $r$ is the average radius (villus width/2) and $\boldsymbol{h}$ is the villi height (Skrzypek et al. 2010).

All data were analyzed using the GLM procedure of SAS 9.0 (SAS 2002). Tukey's multiple range tests were applied to test significant differences between treatments. Variability in the data was expressed as coefficient of variation $(\mathrm{CV})$ and a probability level of $(\mathrm{P}<0.05)$ was considered as statistically significant.

\section{RESULTS AND DISCUSSION}

\section{EXPERIMENT 1}

The use of $\mathrm{AB}$ decreased $(\mathrm{P}<0.05) \mathrm{pH}$ values of diets. This reduction was increasingly higher for the acidifier blend, fumaric acid and fumaric acid in combination with the mixture of acids (Table II). No interactions and no effect of main factors $(\mathrm{P}>0.05)$ were registered on daily feed intake (DFI), daily weight gain (ADG), feed:gain ratio $(F: G)$ and diarrhea incidence (DI) of piglets (Table III) on studied periods. These results corroborate those reported by Gomes et al. (2011), that the addition of $0.5 \%$ of fumaric acid and its combination with $0.5 \%$ lactic acid and $0.5 \%$ calcium propionate did not improve growth performance of piglets weaned at 15-day-old. Similarly, Zentek et al. (2013) found no effect on growth of weanling piglets fed diets containing the mixture of medium-chain fatty acids (capric and caprylic).

The addition of organic acids and their salts in diet of weanling pigs, such as fumaric acid (Giesting and Easter 1991), lactic acid (Tsiloyiannis et al. 2001, Silva 2002), calcium formate (Partanen and Mroz 1999, Bosi et al. 2005) or the combination as lactic acid, formic acid and phosphoric acid (Freitas et al. 2006) have resulted in benefits on growth performance, while other researches have shown 
negative responses on piglets' growth performance due to formic acid usage (Manzanilla et al. 2004) and mixture of fumaric and formic acids (Gomes et al. 2007).

The divergence in results due to usage of acidifiers in weaned piglets diets might be related to differences on raw material composition of experimental diets. Throughout this experiment, the diets had high inclusion of animal protein and lactose, which might be a substrate for microrganisms present in digestive tract, such as Lactobacillus spp., which produces lactic acid and decreases the pH. Owsley et al. (1988) observed that the use of simpler diets based on corn and soybean meal and low inclusion of dairy products have resulted on positive effects after acidifier inclusion. Other reasons for the divergence of results observed in researches performed with acidifiers are the palatability of diets that can inhibit or stimulate consumption, the buffering capacity of diets, the level of acidifier inclusion in diets and the animal's age (Ravindran and Kornegay 1993). In this study, the addition of organic acids in diets had no effect on palatability, since the feed intake was not different among treatments.

The addition of antibiotics and antimicrobial agents as copper sulfate and zinc oxide has also influenced the absence of responses from acidifiers (they might have masked the positive effects of organic acids), since they act similarly to those products (Katouli et al. 1999). Another important factor was high weight at weaning that might have contributed to reduce the organic acids responses, because piglets were healthier and mature (Radecki et al. 1988).

The feed provided to piglets in farrowing stall benefits the development of digestive enzymes activity, improving diet utilization by weaned piglets (Lindemann et al. 1986). The animals of this experiment received pre-starter diets in farrowing rooms, which might have contributed to the absence of acidifiers' responses due to, according to Radecki et al. (1988), this management practice can affect the efficiency of organic acids, once feed consumption in the farrowing house accelerates the maturation of piglets' digestive system at weaning, promoting their greater adaptation.

The diarrhea, the most serious problems of weaned piglets, is characterized by loss of solutes and water, leading to depletion of electrolytes, acid-base imbalance and dehydration, which can be fatal if not treated properly (Zlotowski et al. 2008). The use of additives, such as organic acids and their salts reduces or even eliminates the postweaning diarrhea problems, acting in pathogenic bacteria control (Tsiloyiannis et al. 2001, Mazzoni et al. 2004, Bosi et al. 2005, Roselli et al. 2005, Freitas et al. 2006). No differences ( $\mathrm{P}>0.05)$ were observed on diarrhea incidence among animals (Table III). Similar results reported by Risley et al. (1993) and Braz et al. (2011) found no differences on diarrhea occurrence when diets were evaluated with combinations of organic acids for piglets. The fact that animals had been housed in pens subjected to a long empty period before the beginning of the experiment, although not desinfected, have contributed to a low health challenge what might explain the ineffectiveness of acidifier blend or fumaric acid on diarrhea reduction in piglets kept on that health challenge status.

\section{EXPERIMENT 2}

No FA x AB interaction effects neither differences on $\mathrm{pH}$ values of stomach, jejunum, ileum, colon and rectum $(\mathrm{P}>0.05)$ were registered (Table II). The stomach $\mathrm{pH}$ ranged from 3.10 to 3.68 , which are within the range of pepsin action, that is 1 to 4 (Yamamoto 1975). Gomes et al. (2011) found no statistical differences when added $0.5 \%$ fumaric acid and $0.5 \%$ fumaric acid plus $1 \%$ lactic acid in piglet diets and, reported gastric $\mathrm{pH}$ values of 4.13 and 4.23, respectively, for piglets at 38-day-old. 
TABLE II

Mean pH values of diets and piglets' digestive tract.

Diet-pH values*

\begin{tabular}{|c|c|c|c|c|c|c|c|c|}
\hline Fumaric acid & & Acidifier blend & \multicolumn{2}{|c|}{ PI } & \multicolumn{2}{|c|}{ PII } & & SI \\
\hline \multirow[t]{2}{*}{ Absent } & & Absent & \multicolumn{2}{|c|}{6.29} & \multicolumn{2}{|c|}{6.27} & & 6.17 \\
\hline & & Present & \multicolumn{2}{|c|}{6.08} & \multicolumn{2}{|c|}{6.16} & & 6.14 \\
\hline \multirow{4}{*}{ Present } & & Absent & \multicolumn{2}{|c|}{5.32} & \multicolumn{2}{|c|}{5.32} & \multicolumn{2}{|r|}{5.83} \\
\hline & & Present & \multicolumn{2}{|c|}{5.26} & \multicolumn{2}{|c|}{5.24} & & 5.75 \\
\hline & & & \multicolumn{4}{|c|}{ Segment-pH values** } & & \\
\hline & & & $\mathrm{S}$ & $\mathrm{J}$ & I & $\mathrm{C}$ & $\mathrm{R}$ & \\
\hline \multirow{2}{*}{\multicolumn{2}{|c|}{ Absent }} & Absent & 3.42 & 6.02 & 6.80 & 6.15 & 6.25 & \\
\hline & & Present & 3.82 & 5.58 & 6.78 & 6.12 & 6.48 & \\
\hline \multirow{2}{*}{\multicolumn{2}{|c|}{ Present }} & Absent & 3.10 & 5.62 & 6.88 & 6.02 & 6.43 & \\
\hline & & Present & 3.47 & 5.72 & 6.77 & 6.03 & 6.27 & \\
\hline \multicolumn{9}{|l|}{ Main factors } \\
\hline \multicolumn{9}{|l|}{ Fumaric acid (FA) } \\
\hline & Absent & & 3.62 & 5.80 & 6.79 & 6.13 & 6.37 & \\
\hline & Present & & 3.28 & 5.67 & 6.83 & 6.03 & 6.35 & \\
\hline \multicolumn{9}{|l|}{ Acidifier blend (AB) } \\
\hline & Absent & & 3.26 & 5.82 & 6.84 & 6.08 & 6.34 & \\
\hline & Present & & 3.64 & 5.65 & 6.78 & 6.08 & 6.38 & \\
\hline $\mathrm{FA} \times \mathrm{AB}$ & & & $\mathrm{NS}^{1}$ & $\mathrm{NS}^{1}$ & $\mathrm{NS}^{1}$ & $\mathrm{NS}^{1}$ & $\mathrm{NS}^{1}$ & \\
\hline CV $(\%)^{2}$ & & & 21.48 & 7.55 & 3.47 & 5.53 & 3.76 & \\
\hline
\end{tabular}

*Values of diet-pH from experiment 1. PI = pre-starter I diet; PII = pre-starter II diet; $\mathrm{SI}=$ starter I diet; $\mathrm{S}=$ stomach; $\mathrm{J}=$ jejunum; $\mathrm{I}=$ ileum; $\mathrm{C}=$ colon; $\mathrm{R}=$ rectum. ${ }^{* *}$ Values of segment-pH from experiment $2 .{ }^{1} \mathrm{NS}$ : Non-significant $(\mathrm{P}>0.05) .{ }^{2} \mathrm{Coefficient}$ of variation.

The absence of effects of $\mathrm{AB}$ on $\mathrm{pH}$ of stomach digesta (Risley et al. 1992, Freitas et al. 2006, Bosi et al. 2007, Braz et al. 2011), duodenum pH (Bosi et al. 2007), jejunum pH (Risley et al. 1992) and ileum pH (Gabert and Sauer 1995, Bosi et al. 2007) was similar to the observed in this experiment, suggesting that this is not the most efficient mode of action for acidifiers' usage. The differences on $\mathrm{pH}$ values found in segments of digestive tract might occur depending on the location where measurements were taken, the methodology used and the time after eating (Ferreira 1986). In the present study, sampling was performed after the slaughter of animals, which did not undergo fasting. Another factor that might have influenced the response of acidifier was the lactose inclusion in diets, which is used as substrate for Lactobacillus spp. to produce lactic acid, which in turn reduces the $\mathrm{pH}$.

However, some researches have shown acidifiers efficiency in reducing $\mathrm{pH}$ of stomach digesta (Thomlinson and Lawrence 1981, Bolduan et al. 1988, Maribo et al. 2000), cecum $\mathrm{pH}$ (Maribo et al. 2000) and colon pH (Maribo et 
TABLE III

Means of performance variables at periods 21 to 35, 21 to 49, and 21 to 62 of piglets' age.

\begin{tabular}{|c|c|c|c|c|c|c|c|c|c|c|c|}
\hline \multirow{3}{*}{$\begin{array}{c}\text { Fumaric } \\
\text { acid }\end{array}$} & \multirow{3}{*}{$\begin{array}{l}\text { Acidifier } \\
\text { blend }\end{array}$} & \multicolumn{10}{|c|}{ Growth performance variables } \\
\hline & & \multicolumn{3}{|c|}{ DFI (g) } & \multirow{2}{*}{$\begin{array}{l}\text { DI (\%) } \\
21 \text { to } 35\end{array}$} & \multicolumn{3}{|c|}{ ADG (g) } & \multicolumn{3}{|c|}{ F:G } \\
\hline & & 21 to 35 & 21 to 49 & 21 to 62 & & 21 to 35 & 21 to 49 & 21 to 62 & 21 to 35 & 21 to 49 & 21 to 62 \\
\hline \multirow[t]{2}{*}{ Absent } & Absent & 270 & 555 & 770 & 13.46 & 228 & 383 & 457 & 1.19 & 1.45 & 1.69 \\
\hline & Present & 252 & 530 & 725 & 12.02 & 206 & 388 & 440 & 1.23 & 1.37 & 1.65 \\
\hline \multirow{2}{*}{ Present } & Absent & 250 & 526 & 742 & 12.50 & 200 & 361 & 437 & 1.25 & 1.46 & 1.70 \\
\hline & Present & 263 & 542 & 768 & 13.94 & 215 & 375 & 458 & 1.23 & 1.44 & 1.68 \\
\hline \multicolumn{12}{|c|}{ Main factors } \\
\hline \multicolumn{12}{|c|}{ Fumaric acid (FA) } \\
\hline Abs & ent & 261 & 542 & 748 & 12.74 & 217 & 385 & 448 & 1.20 & 1.41 & 1.68 \\
\hline Pres & sent & 256 & 534 & 756 & 13.22 & 208 & 368 & 448 & 1.24 & 1.45 & 1.69 \\
\hline \multicolumn{12}{|c|}{$\begin{array}{l}\text { Acidifier blend } \\
\text { (AB) }\end{array}$} \\
\hline $\mathrm{Abs}$ & ent & 260 & 540 & 748 & 12.98 & 214 & 372 & 447 & 1.22 & 1.45 & 1.69 \\
\hline Pres & sent & 258 & 536 & 756 & 12.98 & 211 & 381 & 449 & 1.23 & 1.41 & 1.66 \\
\hline $\mathrm{FA} \times \mathrm{AB}$ & & $\mathrm{NS}^{1}$ & $\mathrm{NS}^{1}$ & $\mathrm{NS}^{1}$ & $\mathrm{NS}^{1}$ & $\mathrm{NS}^{1}$ & $\mathrm{NS}^{1}$ & $\mathrm{NS}^{1}$ & $\mathrm{NS}^{1}$ & $\mathrm{NS}^{1}$ & $\mathrm{NS}^{1}$ \\
\hline $\mathrm{CV}(\%)^{2}$ & & 13.5 & 10.7 & 8.71 & 24.66 & 16.2 & 9.95 & 8.52 & 5.70 & 4.61 & 3.45 \\
\hline
\end{tabular}

$\mathrm{DFI}=$ daily feed intake; $\mathrm{DI}=$ diarrhea incidence; $\mathrm{ADG}=$ average daily gain; $\mathrm{F}: \mathrm{G}=$ feed:gain ratio. ${ }^{1} \mathrm{NS}$ : Non-significant $(\mathrm{P}>0.05)$. ${ }^{2}$ Coefficient of variation.

al. 2000, Namkung et al. 2004). The reduction on digesta $\mathrm{pH}$ limits the development of pathogenic microrganisms, such as Escherichia coli, which does not survive in acidic conditions (Barcellos et al. 2007), but usually grows in a $\mathrm{pH}$ range from 5 up to 9 (Zilberstein et al. 1984).

No FA $x$ AB interaction or main factors effects were observed $(\mathrm{P}>0.05)$ on relative weights of stomach, small intestine, cecum, liver, spleen and kidneys. However, the addition of FA in diet determined lower relative weight of pancreas $(\mathrm{P}=$ 0.009) and, the addition of $A B$ resulted on higher relative weight of large intestine $(\mathrm{P}=0.009)$ (Table IV). Similar results were reported by Bhandari et al. (2008), which added the mixture of organic acids in piglet diets and did not observe effect on spleen relative weight, because this organ weight varies depending on the energy and/or protein intake (Rao and McCracken 1992). The diets used in this experiment were isoproteic and had similar levels of metabolizable energy, which could justify the fact that no differences were found on relative weights of stomach, small intestine, cecum, liver, spleen and kidneys.

No FA x AB interaction effects and no effects of main factors $(\mathrm{P}>0.05)$ were observed on villi height (VH) of duodenum, villi width (VW), crypt depth (CD), villi height:crypt depth ratio (VH:CD), and absorption areas of duodenum and jejunum (Table V). The jejunum villi height of piglet fed diet containing fumaric acid was lower $(\mathrm{P}=0.009)$ compared to animals fed diet without FA; however, the jejunal absorption area (Table V) was similar, 
TABLE IV

Mean of organ's relative weights calculated based on empty weight of piglet's carcass.

\begin{tabular}{|c|c|c|c|c|c|c|c|c|c|}
\hline \multirow[b]{2}{*}{$\begin{array}{c}\text { Fumaric } \\
\text { acid }\end{array}$} & \multirow[b]{2}{*}{$\begin{array}{c}\text { Acidifier } \\
\text { blend }\end{array}$} & \multicolumn{8}{|c|}{ Relative weights } \\
\hline & & $\mathbf{S}$ & SG & LG & $\mathrm{CC}$ & $\mathbf{L}$ & $\mathbf{P}$ & SP & KD \\
\hline \multirow{2}{*}{ Absent } & Absent & 0.98 & 5.26 & 1.65 & 0.27 & 2.67 & 0.26 & 0.20 & 0.64 \\
\hline & Present & 0.98 & 5.64 & 1.77 & 0.32 & 2.72 & 0.26 & 0.19 & 0.63 \\
\hline \multirow{2}{*}{ Present } & Absent & 0.91 & 5.37 & 1.64 & 0.29 & 2.65 & 0.25 & 0.22 & 0.61 \\
\hline & Present & 0.90 & 5.51 & 1.77 & 0.28 & 2.68 & 0.23 & 0.20 & 0.58 \\
\hline \multicolumn{10}{|c|}{ Main factors } \\
\hline \multicolumn{10}{|c|}{ Fumaric acid (FA) } \\
\hline \multicolumn{2}{|c|}{ Absent } & 0.98 & 5.45 & 1.71 & 0.29 & 2.69 & $0.26^{\mathrm{a}}$ & 0.19 & 0.63 \\
\hline \multicolumn{2}{|c|}{ Present } & 0.91 & 5.44 & 1.70 & 0.29 & 2.66 & $0.24^{\mathrm{b}}$ & 0.21 & 0.60 \\
\hline \multicolumn{10}{|c|}{ Acidifier blend (AB) } \\
\hline \multicolumn{2}{|c|}{ Absent } & 0.95 & 5.31 & $1.64^{\mathrm{b}}$ & 0.28 & 2.66 & 0.26 & 0.21 & 0.62 \\
\hline \multicolumn{2}{|c|}{ Present } & 0.94 & 5.58 & $1.77^{\mathrm{a}}$ & 0.30 & 2.70 & 0.25 & 0.19 & 0.60 \\
\hline \multicolumn{2}{|l|}{$\mathrm{FA} \times \mathrm{AB}$} & $\mathrm{NS}^{1}$ & $\mathrm{NS}^{1}$ & $\mathrm{NS}^{1}$ & $\mathrm{NS}^{1}$ & $\mathrm{NS}^{1}$ & $\mathrm{NS}^{1}$ & $\mathrm{NS}^{1}$ & $\mathrm{NS}^{1}$ \\
\hline \multicolumn{2}{|l|}{$\mathrm{CV}(\%)^{2}$} & 14.20 & 7.48 & 5.64 & 16.72 & 12.60 & 9.91 & 14.21 & 11.31 \\
\hline
\end{tabular}

$\mathrm{S}=$ stomach; $\mathrm{SG}=$ small intestine; $\mathrm{LG}=$ large intestine; $\mathrm{CC}=$ cecum; $\mathrm{L}=$ liver; $\mathrm{P}=$ pancreas; $\mathrm{SP}=$ spleen; $\mathrm{KD}=$ kidneys. ${ }^{\mathrm{a}, \mathrm{b}}$ Values followed by different letters in the column are statistically different $(\mathrm{P}=0.009)$. ${ }^{1} \mathrm{NS}$ : Non-significant $(\mathrm{P}>0.05) .{ }^{2} \mathrm{Coefficient}$ of variation.

indicating that presence of FA in diet resulted in an increase on villi density.

After evaluate FA inclusion of 0.5 to $1 \%$ in diets, Gomes et al. (2007) found no effects on small intestine morphometric characteristics. In contrast, Bosi et al. (2007) reported greater villi height values in small intestine of piglets weaned at 21-day-old when calcium formate were provided in diets.

The reduction on intestinal villi height of weaned piglets occur at $3^{\text {rd }}$ to $7^{\text {th }}$ days after weaning (Cera et al. 1988) and, the intensity of intestinal disorders are more associated with ingredients used in diet formulation ( $\mathrm{Li}$ et al. 1990) and the quantity of ingested feed (Van Beers-Schreurs et al. 1998). The decrease on villi height are mainly due to the increase in cell desquamation rate (Thomaz et al. 2002) which predisposes animals to nutrient malabsorption, diarrhea and dehydration (Scandolera et al. 2005). Higher VH:CD ratios indicate the presence of increased amount of mature and functional enterocytes, which results in better digestion and absorption of nutrients and also, minor injuries in intestinal mucosa (Tucci et al. 2011).

The animals were kept during the experimental period in a controlled environment, under good conditions of temperature and hygiene, as well as receiving pre-starter diets with high inclusion of lactose, which help to reduce the stress of weaning, contributing to minor changes of intestinal mucosa (Figueiredo et al. 2003, Thomaz et al. 2011).

The nutrient absorption capacity is proportional to density and size of the villi (Macari 1995). Skrzypek et al. (2010) used piglets at 14-day-old 
TABLE V

Means of morphometric variables of piglet's duodenum and jejunum.

\begin{tabular}{|c|c|c|c|c|c|c|}
\hline \multicolumn{7}{|c|}{ Morphometric variables of duodenum } \\
\hline $\begin{array}{c}\text { Fumaric } \\
\text { acid }\end{array}$ & $\begin{array}{c}\text { Acidifier } \\
\text { blend }\end{array}$ & $\begin{array}{c}\mathrm{VH} \\
(\mu \mathrm{m})\end{array}$ & $\begin{array}{c}\text { VW } \\
(\mu \mathrm{m})\end{array}$ & $\begin{array}{c}\text { CD } \\
(\mu \mathrm{m})\end{array}$ & VH:CD & $\mathbf{A A}\left(\mathrm{mm}^{2} / \mathrm{mm}^{2}\right)$ \\
\hline \multirow{2}{*}{ Absent } & Absent & 336 & 161 & 196 & 1.77 & 10.35 \\
\hline & Present & 374 & 154 & 216 & 1.80 & 9.06 \\
\hline \multirow{2}{*}{ Present } & Absent & 345 & 148 & 194 & 1.84 & 8.00 \\
\hline & Present & 318 & 154 & 179 & 1.85 & 7.26 \\
\hline
\end{tabular}

Main factors

Fumaric acid (FA)

\section{Absent}

Present
355

331
157

151
206

187
1.78

1.85
9.71

7.63

Acidifier blend (AB)

$$
\begin{aligned}
& \text { Absent } \\
& \text { Present }
\end{aligned}
$$

FA $x$ AB

$\mathrm{CV}(\%)^{2}$

Absent

$\begin{array}{ll}\text { Absent } & 337 \\ \text { Present } & 374\end{array}$

Present

$\begin{array}{ll}\text { Absent } & 302 \\ \text { Present } & 295\end{array}$

340

346

$\mathrm{NS}^{1}$

16.41

295
155

154

$\mathrm{NS}^{1}$

13.64
195

197

$\mathrm{NS}^{1}$

13.24

\section{Morphometric variables of jejunum}

$\begin{array}{llll}125 & 182 & 1.89 & 4.89 \\ 115 & 190 & 2.03 & 6.10\end{array}$

120

162

1.90

6.29

121

176

1.75

6.68
9.18

8.16

$\mathrm{NS}^{1}$

43.40
.10

68

Main factors

Fumaric acid (AF)

Absent

Present $356^{\mathrm{a}}$

$298^{\mathrm{b}}$
120

121
186

169
1.96

1.82

Acidifier blend (AB)

$\begin{array}{lccccc}\text { Absent } & 319 & 122 & 172 & 1.90 & 5.59 \\ \text { Present } & 335 & 118 & 183 & 1.89 & 6.39 \\ \mathrm{~B} & \mathrm{NS}^{1} & \mathrm{NS}^{1} & \mathrm{NS}^{1} & \mathrm{NS}^{1} & \mathrm{NS}^{1} \\ 2^{2} & 19.84 & 11.04 & 11.16 & 13.70 & 38.54\end{array}$

$\mathrm{VH}=$ villi height; $\mathrm{VW}=$ villi width; $\mathrm{CD}=$ crypt depth; $\mathrm{VH}: \mathrm{CD}=$ villi height:crypt depth ratio; $\mathrm{AA}=$ absorptive area. ${ }^{\mathrm{a}, \mathrm{b}}$ Values followed by different letters in the column are statistically different $(\mathrm{P}=0.009)$. ${ }^{1} \mathrm{NS}$ : Non-significant $(\mathrm{P}>0.05) .{ }^{2} \mathrm{Coefficient}$ of variation. 
and the mean values obtained from duodenum and jejunum absorption area of $9.3 \mathrm{~mm}^{2} / \mathrm{mm}^{2}$ and $14.4 \mathrm{~mm} / \mathrm{mm}^{2}$, respectively were higher than those found in this study for piglets of 35-day-old; although they reported that gut absorption area increased rapidly until $7^{\text {th }}$ day of age, and reduced on $14^{\text {th }}$ day of piglets' age.

The use of ingredients with anti-nutritional factors and/or antigenic protein in diet causes changes on intestinal mucosa, including damage to villi and impair absorption of nutrients (Chamone et al. 2010). The diets used in this experiment were formulated, mostly using highly digestible ingredients, which may have contributed to absence of acidifier effects for most of the variables.

No FA x AB interaction effects were observed on total coliform counts (TC) and Lactobacillus counts (LC) (Table VI). However, animals fed diet containing FA showed lower $(\mathrm{P}<0.05)$ total coliform and Escherichia coli (EC) counts than piglets fed diet without FA, proving the antimicrobial capacity of the acid. The basic principle of FA action is related to its undissociated forms (nonionized, lipophilic form) that diffuse across cell membranes of bacteria, inhibiting their growth through inactivation of bacterial decarboxylases and catalases or even though, over long periods of exposure to FA, desrupting their cell wall (due to an excess of intracellular $\mathrm{H}^{+}$ions) and/or also to the intestinal lumen dissociation that liberates $\mathrm{H}^{+}$ions serving as a $\mathrm{pH}$ barrier against bacteria colonization on brush border (Suiryanrayna and Ramana 2015). Although, after a reduction on total coliform counts, we also expected a reduction on Escherichia coli counts, once these microrganisms constitute the major part of enterobacteria population, the results obtained in this study were contrary to those reported by Risley et al. (1992), which found no reduction on Escherichia coli counts in cecum of weaned piglets fed diet containing 1.5\% FA. These results agreed with results of studies in which the presence of acidifier has determined a reduction on
TABLE VI

Mean cfu-values of piglet's cecum microbiota.

\begin{tabular}{|c|c|c|c|c|}
\hline \multirow{2}{*}{$\begin{array}{l}\text { Fumaric } \\
\text { acid }\end{array}$} & \multirow{2}{*}{$\begin{array}{c}\text { Acidifier } \\
\text { blend }\end{array}$} & \multicolumn{3}{|c|}{$\begin{array}{l}\text { Colony-forming unit (cfu) } \\
\left(\log ^{10} / g\right)\end{array}$} \\
\hline & & TC & EC & $\mathbf{L C}$ \\
\hline \multirow{2}{*}{ Absent } & Absent & 7.15 & 7.02 & 8.78 \\
\hline & Present & 6.91 & 6.50 & 8.51 \\
\hline \multirow{2}{*}{ Present } & Absent & 5.98 & 5.27 & 8.56 \\
\hline & Present & 5.71 & 5.80 & 8.30 \\
\hline \multicolumn{5}{|c|}{ Main factors } \\
\hline \multicolumn{5}{|c|}{ Fumaric acid (FA) } \\
\hline \multicolumn{2}{|c|}{ Absent } & $7.04^{\mathrm{a}}$ & $6.76^{\mathrm{a}}$ & 8.64 \\
\hline \multicolumn{2}{|c|}{ Present } & $5.84^{\mathrm{b}}$ & $5.53^{b}$ & 8.43 \\
\hline \multicolumn{5}{|c|}{ Acidifier blend (AB) } \\
\hline \multicolumn{2}{|c|}{ Absent } & 6.57 & 6.15 & 8.67 \\
\hline \multicolumn{2}{|c|}{ Present } & 6.31 & 6.15 & 8.41 \\
\hline \multicolumn{2}{|c|}{$\mathrm{FA} \times \mathrm{AB}$} & $\mathrm{NS}^{1}$ & $\mathrm{NS}^{1}$ & $\mathrm{NS}^{1}$ \\
\hline \multicolumn{2}{|l|}{$\mathrm{CV}(\%)^{2}$} & 19.37 & 22.87 & 6.72 \\
\hline
\end{tabular}

$\mathrm{TC}=$ total coliform counts; $\mathrm{EC}=$ Escherichia coli counts; $\mathrm{LC}$ = Lactobacillus spp. counts. ${ }^{\mathrm{a}, \mathrm{b}}$ Values followed by different letters in the column are statistically different $(\mathrm{P}=0.009)$. ${ }^{1} \mathrm{NS}$ : Non-significant $(\mathrm{P}>0.05) .{ }^{2}$ Coefficient of variation.

Escherichia coli counts in faeces (Tsiloyiannis et al. 2001, Knarreborg et al. 2002).

The lack of responses regarding the acidifier blend usage confirms the results reported by Walsh et al. (2007), that evaluated a combination of organic acids and did not observe reduction on Escherichia coli counts in weaned piglets fecal content, as well as those described by Torrallardona et al. (2007), that analyzed inclusion of $1.8 \%$ of calcium formate in diets and found no difference on Escherichia coli counts in cecum and ileum of weaned piglets compared to other treatments. Bhandari et al. (2008), working with piglets weaned at 17-dayold and evaluating combinations of organic acids in diets, found no difference on Escherichia coli counts in ileum and cecum among treatments, highlighting that low number of replicates and inherent variability at post-weaning might have 
caused the lack of answers. Moreover, lack of responses on the reduction of total coliform and Escherichia coli counts might also be explained by the low $\mathrm{AB}$ inclusion $(0.3 \%)$ in experimental diets.

\section{CONCLUSIONS}

The inclusion of fumaric acid and the acidifier blend in diets containing colistin or halquinol is not indicated for weaned piglets from 21- to 62-dayold, regarding the growth performance results, $\mathrm{pH}$ values of digesta, relative weight of organs and intestinal morphometry. Also, the fumaric acid exerted inhibitory action on growth of total coliform and Escherichia coli population in piglets' cecum.

\section{REFERENCES}

AOAC - ASSOCIATION OF OFFICIAL ANALYTICAL CHEMISTS. 1990. Official Methods of Analysis, $15^{\text {th }}$ ed., Method 973.41, Arlington: USA, p. 312-313.

AOAC. 2000. Official Methods of Analysis, $17^{\text {th }}$ ed., Method 998.08, Gaithersburg: USA, p. 39-40.

BARCELLOS DESN, SOBESTIANSKY J AND SOBESTIANSKY T. 2007. Uso de antimicrobianos. In: Sobestiansky J and Barcellos DESN (Eds), Doenças dos Suínos. Goiânia: Cânone Editora, p. 685-717.

BARNETT KL, KORNEGAY ET, RISLEY CR, LINDEMANN MD AND SCHURIG GG. 1989. Characterization of creep feed composition and its subsequent effects on immune response, scouring index and performance of weanling pigs. J Anim Sci 67(10): 2698-2708.

BARROW PA, FULLER R AND NEWPORT MJ. 1977. Changes in the microflora and physiology of the anterior intestinal tract of pig weaned at 2 days, with special reference to the pathogenesis of diarrhea. Infect Immun 18: 586-595.

BHANDARI SK, XU B, NYACHOTI CM, GIESTING DW AND KRAUSE DO. 2008. Evaluation of alternatives to antibiotics using an Escherichia coli $\mathrm{K} 88^{+}$model of piglet diarrhea: effects on gut microbial ecology. J Anim Sci 86(4): 836-847.

BLANK R, SAUER WC, MOSENTHIN R, ZENTEK J, HUANG S AND ROTH S. 2001. Effect of fumaric acid supplementation and dietary buffering capacity on the concentration of microbial metabolites in ileal digesta of young pigs. Can J Anim Sci 81(3): 345-353.
BOLDUAN VG, JUNG H, SCHNEIDER R, BLOCK J AND KLENKE B. 1988. Influence of propionic- and formic acid on piglets. J Anim Physiol Anim Nutr 59: 7278 .

BOSI P, SARLI G, CASINI L, DE FILIPPI S, TREVISI P, MAZZONI M AND MERIALDI G. 2005. Effect of dietary addition of free or fat-protected calcium formate on growth, intestinal morphology and health of Escherichia coli K88 challenged weaning pigs. Ital J Anim Sci 4(2): 452-454.

BOSI P, SARLI G, CASINI L, DE FILIPPI S, TREVISI P, MAZZONI M AND MERIALDI G. 2007. The influence of fat protection of calcium formate on growth and intestinal defence in Escherichia coli K88-challenged weanling pigs. Anim Feed Sci Technol 139: 170-185.

BRAZ DB, COSTA LB, BERENCHTEIN B, TSE MLP, ALMEIDA VV AND MIYADA VS. 2011. Acidificantes como alternativa aos antimicrobianos promotores do crescimento de leitões. Arch Zootec 60(231): 745-756.

CERA KR, MAHAN DC, CROSS RF, REINHART GA AND WHITMOYER RE. 1988. Effect of age, weaning and post-weaning diet on small intestinal growth and jejunal morphology in young swine. J Anim Sci 66(2): 574-584.

CHAMONE JMA, MELO MTP, AROUCA CLC, BARBOSA MM, SOUZA FA AND SANTOS D. 2010. Fisiologia digestiva de leitões. Nutritime 7(5): 1353-1363.

CHERRINGTON CA, HINTON M, MEAD GC AND CHOPRA I. 1991. Organic acids: chemistry, antibacterial activity and pratical applications. Adv Microb Physiol 32: 87-108.

COSTA LB, ALMEIDA VV, BERENCHTEIN B, TSE MLP, ANDRADE C AND MIYADA VS. 2011. Aditivos fitogênicos e butirato de sódio como alternativas aos antibióticos para leitões desmamados. Arch Zootec 60(231): 733-744.

DOWNES FP AND ITO K. 2001. Compendium of methods for the microbiological examination of foods, $4^{\text {th }}$ ed., American Public Health Association: Washington, USA, $676 \mathrm{p}$.

FERREIRA AS. 1986. Estimativa de Produção e Composição de Leite de Porca e Aleitamento Artificial de Leitões. Tese de Doutorado. Viçosa: Universidade Federal de Viçosa.

FIGUEIREDO AN, MIYADA VS, UTIYAMA CE AND LONGO FA. 2003. Ovo em pó na alimentação de leitões recém-desmamados. Rev Bras Zootec 32(6): 1901-1911.

FREITAS LS, LOPES DC, FREITAS AF, CARNEIRO JC, CORASSA A, PENA SM AND COSTA LF. 2006. Avaliação de ácidos orgânicos em dietas para leitões de 21 a 49 dias de idade. Rev Bras Zootec 35(4): 1711-1719.

GABERT VM AND SAUER WC. 1995. The effect of fumaric acid and sodium fumarate supplementation to diets for weanling pigs on amino acid digestibility and 
volatile fatty acid concentration in ileal digesta. Anim Feed Sci Technol 53: 243-254.

GIESTING DW AND EASTER RA. 1985. Response of starter pigs to supplementation of corn-soybean meal diets with organic acids. J Anim Sci 60(5): 1288-1294.

GIESTING DW AND EASTER RA. 1991. Effect of protein source and fumaric acid supplementation on apparent ileal digestibility of nutrients by young pigs. J Anim Sci 69(6): 2497-2503.

GOMES FE, FONTES DO, SALIBA EOS, FERREIRA WM, FIALHO ET, SILVA FCO, SILVA MA, CORRÊA GSS AND SALUM GM. 2007. Ácido fumárico e sua combinação com os ácidos butírico ou fórmico em dietas de leitões recém-desmamados. Arq Bras Med Vet Zootec 59(5): 1270-1277.

GOMES FE, FONTES DO, VASCONCELLOS CHF AND SILVA FCO. 2011. Ácido fumárico e sua combinação com ácido lático ou propionato de cálcio em dietas de leitões recém-desmamados. Arq Bras Med Vet Zootec 63(3): 678-686.

KATOULI M, MELIN L, JENSEN-WAERN M, WALLGREN P AND MÖLLBY R. 1999. Effect of zinc oxide supplementation on the stability of the intestinal flora with special reference to composition of coliforms in weaned pigs. J Appl Microbiol 87(4): 564-573.

KNARREBORG A, MIQUEL N, GRANLI T AND JENSEN BB. 2002. Establishment and application of an in vitro methodology to study the effects of organic acids on coliform and lactic acid bacteria in the proximal part of the gastrointestinal tract of piglets. Anim Feed Sci Technol 99: 131-140.

LI DF, NELSSEN JL, REDDY PG, BLECHAF, HANCOCK JD, ALLEE GL, GOODBAND RD AND KLEMM RD. 1990. Transient hypersensivity to soybean meal in the early-weaned pig. J Anim Sci 68(6): 1790-1799.

LINDEMANN MD, CORNELIUS SG, EL KANDELGY SM, MOSER RL AND PETTIGREW JE. 1986. Effect of age, weaning and diet on digestive enzyme levels in the piglet. J Anim Sci 62(5): 1298-1307.

MACARI M. 1995. Mecanismos de proliferação e reparação da mucosa gastrintestinal em aves. In: Simpósio de Coccidiose e Enterite, 1. Proceedings ... Campinas: [s.n.].

MANZANILLA EG, PEREZ JF, MARTIN M, KAMEL C, BAUCELLS F AND GASA J. 2004. Effect of plant extracts and formic acid on the intestinal equilibrium of early-weaned pigs. J Anim Sci 82(11): 3210-3218.

MARIBO H, JENSEN BB AND HEDEMANN MS. 2000. Different doses of organic acids for weaned piglets. In: The National Committee for Pig Production, Denmark: Danish Bacon and Meat Council, report 469.

MAZZONI M, LALATTA COSTERBOSA G, CASINI L, PETROSINO G, TREVISI P, DE FILIPPI S AND BOSI P. 2004. La morfologia dello stomaco come parametro di valutazione dell'impiego di acidificante nella dieta del suino in svezzamento. Società Italiana dele Scienze Veterinarie 56: 240. http:/www.ismea.it/ flex/AppData/Redational/Normative/D.1e1 aaa02ed5d 4f958508/200760651.pdf.

NAMKUNG H, LI M, GONG J, YU H, COTTRILL M AND LANGE CFM. 2004. Impact of feeding blends of organic acids and herbal extracts on growth performance, gut microbiota and digestive function in newly weaned pigs. Can J Anim Sci 84(4): 697-704.

OWSLEY WF, HAYDON KD AND JONES RD. 1988. Effects of organic acid addition and diet complexity on performance of pigs weaned at 28 days. J Anim Sci 66(2): $1-41$.

PARTANEN K. 2002. Using organic acids in pig feeding as an alternative to antibiotics feed additives. In: Simpósio sobre Manejo e Nutrição de Aves e Suínos e Tecnologia na Produção de Rações. Proceedings... Campinas: Colégio Brasileiro de Nutrição Animal, p. 45-62.

PARTANEN KH AND MROZ Z. 1999. Organic acids for performance enhancement in pig diets. Nutr Res Rev 12(1): $117-145$.

RADCLIFFE JS, ZHANG Z AND KORNEGAY ET. 1998. The effects of microbial phytase, citric acid, and their interaction in a corn-soybean meal-based diet for weanling pigs. J Anim Sci 76(7): 1880-1886.

RADECKI SV, JUHL MR AND MILLER ER. 1988. Fumaric and citric acids feed additives in starter pig diets: effect on performance and nutrient balance. J Anim Sci 66(10): 2598-2605.

RAO DS AND MCCRACKEN KJ. 1992. Energy: protein interactions in growing boars on high genetic potential for lean growth. 1. Effects on growth, carcass characteristics and organ weights. Anim Prod 54(1): 75-82.

RAVINDRAN V AND KORNEGAY ET. 1993. Acidification of weaner pig diets: a review. J Sci Food Agr 62(4): $313-$ 322.

RISLEY CR, KORNEGAY ET, LINDEMANN MD, WOOD CM AND EIGEL WN. 1992. Effects of feeding organic acids on selected intestinal content measurements at varying times postweaning in pigs. J Anim Sci 70(1): 196-206.

RISLEY CR, KORNEGAY ET, LINDEMANN MD, WOOD CM AND EIGEL WN. 1993. Effect of feeding organic acids on gastrointestinal digesta measurements at various times postweaning in pigs challenged with enterotoxigenic Escherichia coli. Can J Anim Sci 73(4): 931-940.

ROSELLI M, FINAMORE A, BRITTI MS, BOSI P, OSWALD I AND MENGHERI E. 2005. Alternatives to in-feed antibiotics in pigs: Evaluation of probiotics, zinc or organic acids as protective agents for the intestinal 
mucosa. A comparison of in vitro and in vivo results. Anim Res 54: 203-218.

ROSTAGNO HS, ALBINO LFT, DONZELE JL, GOMES PC, OLIVEIRA RF, LOPES DC, FERREIRA AS, BARRETO SLT AND EUCLIDES RF. 2011. Composição de alimentos e exigências nutricionais de aves e suínos (tabelas brasileiras), $3^{\text {a }}$ ed., Viçosa: Universidade Federal de Viçosa, $252 \mathrm{p}$.

SAS. 2002. SAS/STAT® User's Guide: version 9, $6^{\text {th }}$ ed., SAS Institute Inc.: Cary, NC, USA.

SCANDOLERA AJ, THOMAZ MC, KRONKA RN, FRAGA AL, BUDIÑO FEL, ROBLES-HUAYNATE RA, RUIZ US AND CRISTANI J. 2005. Efeitos de fontes protéicas na dieta sobre morfologia intestinal e desenvolvimento pancreático de leitões recémdesmamados. Rev Bras Zootec 34(6): 2355-2368.

SILVA MC. 2002. Efeito da adição de acidificantes e suas combinações na alimentação de leitões desmamados sobre o desempenho. In: Reunião Anual da Sociedade Brasileira de Zootecnia, Recife. Proceedings ... Campinas: ABZ.

SKRZYPEK T, VALVERDE PIEDRA JL, SKRZYPEK H, KAZIMIERCZAK W, SZYMANCZYK SE AND ZABIELSKI R. 2010. Changes in pig small intestinal absorptive area during the first 14 days of life. Livest Sci 133: 53-56.

SUIRYANRAYNA MVAN AND RAMANA JV. 2015. A review of the effects of dietary organic acids fed to swine. J Anim Sci Biotechnol 6(45): 1-11.

THOMAZ MC, HANNAS MI, KRONKA RN, TUCCI FM, SCANDOLERA AJ AND BUDIÑO FEL. 2011. Plasma suíno e ovo inteiro em rações de leitões desmamados sobre a estrutura e ultra-estrutura da muscosa intestinal. Ars Vet 27(4): 246-254.

THOMAZ MC, TUCCI FM AND KRONKA RN. 2002. Efeitos da adição de glutamina, ácidos graxos poliinsaturados ou parede celular de levedura na dieta de leitões desmamados sobre a estrutura do intestino delgado. In: Reunião Anual da Sociedade Brasileira de Zootecnia, Recife. Proceedings.... Campinas: ABZ.

THOMLINSON JR AND LAWRENCE TL. 1981. Dietary manipulation of gastric $\mathrm{pH}$ in the prophylaxis of enteric disease in weaned pigs: some field observations. Vet Rec 109(6): 120-122.

TORRALLARDONA D, CONDE R, BADIOLA I AND POLO J. 2007. Evaluation of spray dried animal plasma and calcium formate as alternatives to colistin in piglets experimentally infected with Escherichia coli K99. Livest Sci 108: 303-306.

TSILOYIANNIS VK, KYRIAKIS SC, VLEMMAS J AND SARRIS K. 2001. The effect of organic acids on the control of porcine post-weaning diarrhoea. Res Vet Sci 70(3): 287-293.

TUCCI FM, THOMAZ MC, NAKAGHI LSO, HANNAS MI, SCANDOLERA AJ AND BUDIÑO FEL. 2011. Efeito da adição de agentes tróficos na dieta de leitões desmamados sobre a estrutura e ultraestrutura do intestino delgado e sobre o desempenho. Arq Bras Med Vet Zootec 63(4): 931-940.

VAN BEERS-SCHREURS HM, NABUURS MJ, VELLENGA L, VAN DER KALSBEEK HJ, WENSING T AND BREUKINK HJ. 1998. Weaning and the weanling diet influence the villous height and crypt depth in the small intestine of pigs and alter the concentrations of shortchain fatty acids in the large intestine and blood. J Nutr 128(6): 947-953.

VENTE-SPREEUWENBERG MA, VERDONK JM, VERSTEGEN MW AND BEYNEN AC. 2003. Villus height and gut development in weaned piglets receiving diets containing either glucose, lactose or starch. Brit J Nutr 90(5): 907-913.

WALSH MC, SHOLLY DM, HINSON RB, TRAPP SA, SUTTON AL, RADCLIFFE JS, SMITH JW AND RICHERT BT. 2007. Effects of acid LAC and KemGest acid blends on growth performance and microbial shedding in weanling piglets. J Anim Sci 85(2): 459-467.

YAMAMOTO A. 1975. Proteolytic enzymes. In: Reed G (Eds), Enzymes in food processing, Holland: Elsevier, $2^{\text {nd }}$ ed., p. 123-179.

ZENTEK J, FERRARA F, PIEPER R, TEDIN L, MEYER W AND VAHJEN W. 2013. Effects of dietary combinations of organic acids and medium chain fatty acids on the gastrointestinal microbial ecology and bacterial metabolites in the digestive tract of weaning piglets. J Anim Sci 91(7): 3200-3210.

ZILBERSTEIN D, AGMON V, SCHULDINER S AND PADAN E. 1984. Escherichia coli intracellular pH, membrane potential, and cell growth. J Bacteriol 158(1): 246-252.

ZLOTOWSKI P, DRIEMEIER D AND BARCELLOS DESN. 2008. Patogenia das diarréias dos suínos: modelos e exemplos. Acta Sci Vet 36(1): S81-S86. 